\title{
Asymptomatic urinary tract infection among pregnant women attending the antenatal clinic of Hawassa Referral Hospital, Southern Ethiopia
}

\author{
Endale Tadesse ${ }^{1 *}$, Million Teshome ${ }^{2}$, Yared Merid $^{3}$, Belayhun Kibret ${ }^{4}$ and Techalew Shimelis ${ }^{1}$
}

\begin{abstract}
Background: Untreated asymptomatic bacteriuria (ASB) during pregnancy may cause serious complications including pyelonephritis and delivery of premature or low-birth-weight infants. However, little is known about asymptomatic bacteriuria in pregnancy in Ethiopia. This study aimed to assess the prevalence of asymptomatic bacteriuria, bacterial agents, and their antibiotic susceptibility pattern in pregnant women attending antenatal clinic of the Hawassa Teaching and Referral Hospital.

Methods: A cross-sectional study was conducted in a total of 244 pregnant women with no sign and symptom of urinary tract infection from March 2012 to September 2012. Clean catch mid-stream urine samples were collected from all study participants using sterile containers. Urine samples were cultured using standard bacteriological methods. Identification of suspected colonies and antibiotic sensitivity testing were done.

Result: Out of 244 pregnant women, 46(18.8\%) were positive for asymptomatic bacteriuria (Colony Forming Unit $\geq$ $\left.10^{5} / \mathrm{mL}\right)$. There was no difference in prevalence of asymptomatic bacteriuria with respect to age $(p=0.07)$ and trimester $(p=0.27)$.The most frequently isolated bacteria were coagulase negative Staphylococcus (32.6\%), followed by Escherichia coli (26.1\%), and Staphylococcus auerus (13\%). The susceptibility rate of bacterial isolate was highest for norfloxacin (64.7\%) and lowest for ampicillin (17.6\%).
\end{abstract}

Conclusion: The high prevalence of ASB in pregnant women warrant the need to screen all pregnant women and treat those infected with appropriate antimicrobial regimens in order to reduce its complications.

Keywords: Asymptomatic bacteriuria, Urinary tract infection, Pregnant women

\section{Background}

Urinary tract infection (UTI) is a common health problem among women compared with men due to shorter urethra, closer proximity of the anus with vagina, and pathogen entry facilitated by sexual activity [1,2]. It is estimated that one in three women of childbearing age contracts UTI [3], which may manifest symptoms or remain asymptomatic. Pregnant women are more susceptible to UTI, owing to altered anatomical and physiological state during pregnancy [2].

Asymptomatic bacteriuria (ASB) is a presence of a significant quantity of bacteria in a properly collected urine

\footnotetext{
*Correspondence: endaletd@yahoo.com

'Department of Medical Laboratory Science, College of Medicine and Health Sciences, Hawassa University, P.O. Box 1560, Hawassa, Ethiopia

Full list of author information is available at the end of the article
}

specimen from a person without symptoms or signs of UTI [4]. A prevalence of asymptomatic UTI ranging from $2 \%$ to $15 \%$ was reported compared to symptomatic UTI in pregnant women [5]. Socioeconomic factors and past history of asymptomatic urinary tract infection were related with UTI in pregnancy [6,7]. About 30\% of women with untreated asymptomatic bacteriuria during pregnancy develop pyelonephritis [3], which might lead to delivery of premature or low-birth-weight infants [8,9].

In Ethiopia, studies reported prevalence of asymptomatic bacteria among pregnant women to range from $7 \%$ to $10.6 \%$ [10,11]. Bacteria including Escherichia coli, Staphylococcus aureus, Providencia species, Klebsiella species and Staphylococcus saprophyticus [12-14] were commonly isolated from pregnant women with UTI. However, in most developing countries including Ethiopia,

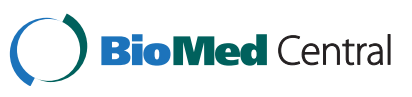


screening for ASB in pregnancy is not considered as an essential part of antenatal care. Little is also known regarding the epidemiology of asymptomatic bacteriuria in pregnant women in southern Ethiopia. This study therefore aimed to determine the magnitude of asymptomatic bacteriuria, type of bacterial etiology and their antibiotic susceptibility pattern in pregnant women attending antenatal clinic of the Hawassa Teaching and Referral Hospital, southern Ethiopia.

\section{Methods}

A cross-sectional study was conducted at Hawassa Teaching and Referral Hospital, southern Ethiopia from March 2012 to September 2012. The hospital is located at Hawassa, which is the capital city of South Nations, Nationalities and People's Regional state, and the largest in the administrative region.

The study population comprised of all pregnant women attending the antenatal clinic in the hospital during the study period. However, pregnant women who were on antibiotic treatment two weeks prior to data collection and those with clinical signs and symptoms of UTI were excluded. The sample size was estimated using $6 \%$ prevalence [10], 3\% margin of error and 95\% confidence level. In total, 244 pregnant women were included in the study.

Demographic data including age and pregnancy gestational age was collected using questionnaires. Clean catch mid-stream urine samples were collected from all participants using wide-mouthed sterile capped container. The specimen was promptly transported to Microbiology laboratory and cultured within one hour of collection. Briefly, about $0.002 \mathrm{ml}$ of samples were inoculated on Cystine Lysine Electrolyte Deficient (CLED) agar, Mannitol salt agar (MSA), and blood agar plate (Oxoid Basingstoke, UK) and incubated aerobically at $37^{\circ} \mathrm{C}$ for 24 hours. Bacterial growth was categorized and interpreted on the basis of colony forming units (CFU) as follows: equal to or greater than $10^{5} \mathrm{CFU} / \mathrm{ml}$ was considered as positive; less than $10^{5} \mathrm{CFU} / \mathrm{ml}$ were contamination. Bacterial isolates were identified based on their characteristic appearance, Gram reaction and pattern of biochemical reactions.

Antimicrobial susceptibility test was performed using disk-diffusion method on Müller-Hinton agar medium (Oxoid Basingstoke, UK) according to the instruction of the Clinical and Laboratory Standards Institute [15]. Antibiotic discs tested against bacterial isolates were trimethoprim-sulphamethoxazole (SXT, $25 \mu \mathrm{g})$, gentamicin (CN, $10 \mu \mathrm{g})$, cefotaxime (CTX, $30 \mu \mathrm{g})$, ampicillin (AMP, $10 \mu \mathrm{g}$ ), penicillin (P, $10 \mathrm{IU}$ ), vancomycin (VA, $30 \mu \mathrm{g}$ ) and norfloxacin (NOR, $10 \mu \mathrm{g}$ ) (Oxoid Basingstoke, UK). Reference strains of E. coli (ATCC- 25922) and $S$. aureus (ATCC-25923) were tested as controls.

Data entry and analysis was performed using SPSS V-16. Descriptive summaries were presented, and Chi-square test $\left(\mathrm{x}^{2}\right)$ was used to assess difference between proportions. P-value less than 0.05 was considered as statistically significant.

The study was ethically approved by the Institutional Review Board of College of Medicine and Health Sciences, Hawassa University. Participation was fully voluntary; and consent was obtained from all participants. Any information obtained during the study was kept confidential, and Doctors manage those women with UTI.

\section{Results}

Single urine samples collected from a total of 244 pregnant women were examined for ASB. The mean age of the study participants was $26.13(\mathrm{SD}=6.37$, range $=$ $15-49)$. The majority of the pregnant women were in their 3rd trimester (45.1\%) and 2nd trimester (41\%). Of the analyzed urine samples, 46 (18.8\%) were positive for significant bacteriuria (CFU $\geq 10^{5} / \mathrm{mL}$ ). The rate of isolation was higher in the age group $\geq 35$ year $(41.67 \%)$, though the difference was not statistically significant $(\mathrm{p}=0.07)$. Women at their 2 nd and 3rd trimester had a respective 20\% and $20.9 \%$ rates of ASB, though this difference was also statistically non-significant $(\mathrm{p}=0.27)$ (Table 1 ).

Table 1 Distribution of ASB by age group and trimester among pregnant women at Hawassa Teaching and Referral Hospital, 2012

\begin{tabular}{llll}
\hline Characteristic & Total tested (\%) & Number (\%) positive & Chi-square value \\
\hline Age (years) & & & \\
$15-24$ & $90(36.9)$ & $19(21.1)$ & 5.43 \\
$25-34$ & $142(58.2)$ & $22(15.5)$ & \\
$\geq 35$ & $12(4.9)$ & $5(41.67)$ & \\
Total & $\mathbf{2 4 4 ( 1 0 0 )}$ & $\mathbf{4 6 ( 1 8 . 8 )}$ & \\
Trimester & & & 2.626 \\
1st trimester & $34(13.9)$ & $3(8.8)$ & \\
2nd trimester & $100(41.0)$ & $20(20)$ & \\
3rd trimester & $110(45.1)$ & $23(20.9)$ & \\
\hline
\end{tabular}


Table 2 Pattern of single and mixed bacterial infections among pregnant women attending Hawassa Teaching and Referral Hospital, 2012

\begin{tabular}{ll}
\hline Pattern of single and mixed bacterial isolates & Frequency (\%) \\
\hline Single infection & \\
Staphylococcus auerus & $6(13)$ \\
CoNS & $15(32.6)$ \\
Escherichia coli & $12(26.1)$ \\
Klebsiella species & $3(6.5)$ \\
Pseudomonas aeruginosa & $1(2.2)$ \\
Enterobacter species & $4(8.7)$ \\
Mixed infection & \\
CoNS and Escherichia coli & $4(8.7)$ \\
Staphylococcus auerus and Citrobacter species & $1(2.2)$ \\
Total & $\mathbf{4 6}(\mathbf{1 0 0})$
\end{tabular}

CoNS = Coagulase negative Staphylococci.

The majority $(89.1 \%)$ of the infected women had single infection; while $10.9 \%$ were dually infected, which makes the total number of bacterial isolates 51 (Table 2). Of the bacterial isolates, 26 (51\%) were Gram-positive bacteria and the rest 25 (49\%) were Gram-negative bacteria. The predominant bacterial species were coagulase negative Staphylococcus (CoNs) (32.6\%), E. coli (26.1\%), S. auerus (13\%), Enterobacter species 4(8.7), and Klebsiella species $3(6.5 \%)$. CoNS and $E$. coli was responsible for 4 (8.7\%) of mixed infection.

Antimicrobial susceptibility of isolated bacteria showed that: norfloxacin (64.7\%), gentamicin (47.1\%), cefotaxime (43.15\%), penicillin (30.8\%), trimethoprim-sulphamethoxazole (25.5\%), vancomycin (23.5\%), and ampicillin (17.3) (Table 3). Multi-drug resistance (resistance two or more drugs) was observed in all isolated bacteria.

\section{Discussion}

Pregnant women are at increased risk of UTI but in many cases, infection remains asymptomatic [2]. In this study, the prevalence of asymptomatic urinary tract infection among pregnant women attending antenatal clinic of Hawassa Teaching and Referral Hospital was $18.8 \%$, which is similar with previous work in northwest Ethiopia (Bahirdar) [16]. It is, however, higher than results from southwest (Jimma) [10], northwest (Gondar) [17], and central Ethiopia (Addis Ababa) [11], where rates ranging from 6 to $10.6 \%$ were reported. Our finding is lower than the figure reported from Iran (29.1\%) [18] and Sagamu (23.9\%) [19], Benin (45.3\%) [20] and Abakaliki cities of Nigeria (78.7\%) [21]. The varying prevalence of ASB from one country to another and among regions of the same country might be due to difference in risk factors with geographical areas.

The highest rate of ASB was reported in the age group $\geq 35$ years and the lowest was in the age group 25-34 years. Similarly, higher infection rates were shown in the age group 25-29 years elsewhere [22,23]. Moreover, similar to previous findings by Okonko et al. [22] and Turpin et al. [23], the prevalence of asymptomatic bacteriuria has no significant association with trimester.

The predominant bacterial isolates observed in this study were CoNS (32.6\%) followed by E. coli (26.1\%), and S. auerus (13\%). In agreement, Rahimkhani et al. [18] reported S. epidermidis (36\%) and E. coli (20\%) as prevailing bacterial isolates. The predominance of $E$. coli was also consistently reported by others [11,16-18,21,22,24]. High prevalence rate of staphylococci $(45.6 \%)$ in this study were surprising result. This could be due to poor genital hygienic practices by pregnant women who may find it difficult to clean their anal or genital region properly after defecating or passing urine.

In this study, the traditional semi-quantitative bacterial counts (s-QBC) cut-off of value $10^{5} \mathrm{CFU} / \mathrm{ml}$ was used to define significant bacteriuria. However, recent studies have reported that this cut-off is insensitive and inappropriate for some clinical conditions and proposed lower s-QBC value cut-off, $10^{3} \mathrm{CFU} / \mathrm{ml}[25,26]$. Tan et al. also showed that using a lower threshold of $\geq 10^{3}$ s-QBC

Table 3 Antibiotics Sensitivity Pattern of Bacterial isolates at Hawassa Referral and Teaching Hospital, 2012

\begin{tabular}{|c|c|c|c|c|c|c|c|c|}
\hline \multirow[t]{2}{*}{ Bacterial isolates } & \multicolumn{8}{|c|}{ No. of strains sensitive to Antibiotics (\%) } \\
\hline & No. & AMP & $\mathrm{CN}$ & $\mathbf{P}$ & SXT & NOR & VA & CTX \\
\hline Staphylococcus auerus & 7 & $0(0.0)$ & $2(28.6)$ & $2(28.6)$ & $4(57.1)$ & $4(57.1)$ & $6(85.7)$ & $4(57.1)$ \\
\hline CoNS & 19 & $2(10.5)$ & $8(42.1)$ & 6(31.6) & $4(21.1)$ & 10(52.6) & $2(10.5)$ & $7(36.8)$ \\
\hline Escherichia coli & 16 & $5(31.2)$ & $9(56.2)$ & - & $3(18.8)$ & 13(81.2) & $3(18.8)$ & $9(56.2)$ \\
\hline Citrobacter species & 1 & $0(0.0)$ & $1(100.0)$ & - & $0(0.0)$ & $0(0.0)$ & $0(0.0)$ & $0(0.0)$ \\
\hline Klebsiella species & 3 & $1(33.3)$ & $3(100.0)$ & - & $1(33.3)$ & $2(66.7)$ & $1(33.3)$ & $1(33.3)$ \\
\hline Pseudomonas aeruginosa & 1 & $0(0.0)$ & $1(100.0)$ & - & $0(0.0)$ & $1(100.0)$ & $0(0.0)$ & $0(0.0)$ \\
\hline Enterobacter species & 4 & $1(25.0)$ & $0(0.0)$ & - & $1(25.0)$ & $3(75.0)$ & $0(0.0)$ & $1(25.0)$ \\
\hline Total & 51 & $9(17.6)$ & 24(47.1) & $8(30.8)$ & $13(25.5)$ & $33(64.7)$ & $12(23.5)$ & $22(43.1)$ \\
\hline
\end{tabular}

CoNS = coagulase negative Staphylococci; $\mathrm{AMP}=$ ampicillin; $\mathrm{CN}=$ gentamicin; $\mathrm{P}$ = penicillin; SXT = trimethoprim-sulphamethoxazole; NOR = norfloxacin; $\mathrm{VA}=$ vancomycin; $\mathrm{CTX}=$ cefotaxime . 
would be appropriate for diagnosis of group B streptococcus (GBS) urinary tract infection [25]. The absence of GBS in our study, in contrast to others findings $[5,27,28]$, may be due to the higher cut-off we used.

The susceptibility of bacterial isolates against norfloxacin, gentamicin and cefotaxime was $64.7 \%, 47.1 \%$ and $43.1 \%$ respectively. However, slightly higher susceptibility rates were reported for these antibiotics in Gondar [29] and Addis Ababa [11], which probably be due to widespread misuse of antibiotics in those areas.

\section{Conclusion}

In conclusion, the prevalence of ASB in pregnant women was relatively higher than previous findings in Ethiopia. This study also showed, most of bacterial isolates are resistant against commonly used antimicrobial agents. Therefore, routine laboratory diagnosis of ASB in pregnant women and providing appropriate treatment would be needed to reduce its complications.

\section{Abbreviations \\ ABU: Asymptomatic bacteruria; UTI: Urinary tract infection; CFU: Colony forming unit; CoNS: Coagulase negative Staphylococci; GBS: Group B streptococcus; s-QBC: Semi-quantitative bacteruria count.}

\section{Competing interests}

We declare that we have no competing interests.

\section{Authors' contributions}

ET was the principal investigator for the study: TS, MT, BK and YM contributed to the design of the study. ET and YM carried out laboratory work. TS and ET performed statistical analysis and interpreted the result. All authors contributed to the write up of the manuscript.

\section{Acknowledgements}

The authors would like to thank Hawassa University for funding the research and Ms. Sara Tadesse for technical assistance during laboratory work. We also extend our appreciation to the study subjects who voluntarily participated in the study.

\section{Author details}

${ }^{1}$ Department of Medical Laboratory Science, College of Medicine and Health Sciences, Hawassa University, P.O. Box 1560, Hawassa, Ethiopia. ${ }^{2}$ Gynaecology and Obstetrics Unit, College of Medicine and Health Sciences, Hawassa University, P.O. Box 1560, Hawassa, Ethiopia. ${ }^{3}$ Medical Microbiology and Parasitology Unit, College of Medicine and Health Sciences, Hawassa University, P.O. Box 1560, Hawassa, Ethiopia. ${ }^{4}$ Biochemistry Unit, College of Medicine and Health Sciences, Hawassa University, P.O. Box 1560, Hawassa, Ethiopia.

Received: 9 July 2013 Accepted: 10 March 2014 Published: 17 March 2014

\section{References}

1. Feitosa DCA, Silva MG, Parada CMGL: Accuracy of simple urine tests for diagnosis of urinary tract infections in low-risk pregnant women. Rev Latino-am Enfermagem 2009, 17(4):507-13.

2. Abdullah AA, Al-Moslih MI: Prevalence of asymptomatic bacteriuria inpregnant women in Sharjah, United Arab Emirates. East Mediterr Health J 2005, 11:5-6.

3. Duarte G, Marcolin AC, Quintana SM, Cavalli RC: Urinary tract infection in pregnancy. Rev Bras Ginecol Obstet 2008, 30:93-100.

4. Schnarr J, Smaill F: Asymptomatic bacteriuria and symptomatic urinary tract infections in pregnancy. Eur J Clin Invest 2008, 38(2):50-57.
5. Ipe DS, Sundac L, Benjamin WH Jr, Moore KH, Ulett GC: Asymptomatic bacteriuria: prevalence rates of causal microorganisms, etiology of infection in different patient populations, and recent advances in molecular detection. FEMS Microbiol Lett 2013, 346(1):1-10.

6. Turck M, Goffe BS, Petersdorf RG: Bacteriuria of pregnancy. Relation to socioeconomic factors. N Engl J Med 1962, 266:857-860.

7. Nicolle LE: Screening for asymptomatic bacteriuria in pregnancy. In Canadian Guide on preventive health care. Ottawa: Health Canada; 1994:100-106.

8. Schults R, Read AW, Straton JAY, Stanley FJ, Morich P: Genitourinary tract infection in pregnancy and low birth weight: case control study in Australian aboriginal women. Brit Med J 1991, 73:576-582.

9. MedMcGregor JA, French JI, Richter R, Franco-Buff A, Johnson A, Hillier S, Judson FN, Todd JK: Antenatal microbiologic and maternal risk factors associated with prematurity. Am J Obstet Gynecol 1990, 163:1465-1473.

10. Gabre-Selassie S: Asymptomatic bacteriuria in pregnancy; epidemiological clinical and microbiological approach. Ethiop Med J 1998, 36:185-192.

11. Assefa A, Asrat D, Woldeamanuel $Y, G /$ Hiwot $Y$, Abdella A, Melesse T: Bacterial profile and drug susceptibility pattern of urinary tract infection in pregnant women at Tikur Anbessa Specialized Hospital, Addis Ababa, Ethiopia. Ethiop Med J 2008, 46:227-35.

12. Delzell JE, Lefevre ML: Urinary tract infections during pregnancy. Am Fam Physician 2000, 61(3):713-21.

13. MacLean $A B$ : Urinary tract infection in pregnancy. Int J Antimicrob Agents 2001, 17:273-6.

14. Khan $A U$, Zaman MS: Multidrug resistance pattern in urinary tract infection patients in Aligarh India. Bio Med Research 2006, 17:179-181

15. Barry AL, Thornberry C: Susceptibility Tests: Diffusion test procedures. In Manual of Clinical Microbiology. 5th edition. Edited by Ballow A, et al. Washington D.C: American Society for Microbiology; 1991:1117-1125

16. Demilie T, Beyene G, Melaku S, Tsegaye W: Urinary bacterial profile and antibiotic susceptibility pattern among pregnant women in North West Ethiopia. Ethiop J Health Sci 2012, 22(2):121-128.

17. Tadesse A, Negash M, Ketema LS: Asymptomatic bacteriuria in pregnancy: assessment of prevalence, microbial agents and their antimicrobial sensitivity pattern in Gondar Teaching Hospital, North West Ethiopia. Ethiop Med J 2007, 45:143-9.

18. Rahimkhani M, Khavari-Daneshvar H, Sharifian R: Asymptomatic bacteriuria and pyuria in pregnancy. Acta Med Iran 2008, 46(5):409-412.

19. Olusanya O, Ogunledum A, Fakoya TA: Asymptomatic significant bacteriuria among pregnant and non pregnant women in Sagamu, Nigeria. WAJM 1993, 12(1):27-33.

20. Imade PE, Izekor PE, Eghafona NO, Enabulele OI, Ophori E: Asymptomatic bacteriuria among pregnant women. North Am J Med Sci 2010, 2:263-266.

21. Amadi ES, Enemuo OB, Uneke CJ, Nwosu OK, Onyeagba RA, Ugbogu OC: Asymptomatic bacteriuria among pregnant women in Abakaliki, Ebonyi State. Nigeria J Med Sci 2007, 7(4):698-700.

22. Okonko IO, ljandipe LA, Ilusanya OA, Ejembi J, Udeze AO, Egun OC, Fowotade A, Nkang AO: Incidence of urinary tract infection (UTI) among Pregnant women in Ibadan, South-Western Nigeria. Afr J Biotechnol 2009, 8:6649-6657.

23. Turpin CA, Minkah B, Danso KA, Frimpong EH: Asymptomatic bacteriuria in pregnant women. Ghana Med J 2007, 4(7):26-29.

24. Obirikorang C, Quaye L, Bio FY, Amidu N, Acheampong I, Addo K: Asymptomatic Bacteriuria among Pregnant Women Attending Antenatal Clinic at the University Hospital, Kumasi, Ghana. Journal of Medical and Biomedical Sciences 2012, 1(1):38-44.

25. Tan CK, Ulett KB, Steele M, Benjamin WH Jr, Ulett GC: Prognostic value of semi-quantitative bacteriuria counts in the diagnosis of group $B$ streptococcus urinary tract infection: a 4-year retrospective study in adult patients. BMC Infect Dis 2012, 12:273.

26. Wilson ML, Gaido L: Laboratory diagnosis of urinary tract infections in adult patients. Clin Infect Dis 2004, 38(8):1150-1158.

27. Munoz P, Coque T, Rodriguez Creixems M, de Quiros JCB, Moreno S, Bouza E: Group B Streptococcus: a cause of urinary tract infection in nonpregnant adults. Clin Infect Dis 1992, 14(2):492-496. 
28. Ulett GC: Diversity of group B streptococcus serotypes causing urinary tract infection in adults. J Clin Microbiol 2009, 47(7):2055-2060.

29. Alemu A, Moges F, Shiferaw Y, Tafess K, Kassu A, Anagaw B, Agegn A: Bacterial profile and drug susceptibility pattern of urinary tract infection in pregnant women at University of Gondar Teaching Hospital, Northwest Ethiopia. BMC Research Notes 2012, 5:197.

doi:10.1186/1756-0500-7-155

Cite this article as: Tadesse et al:: Asymptomatic urinary tract infection among pregnant women attending the antenatal clinic of Hawassa Referral Hospital, Southern Ethiopia. BMC Research Notes 2014 7:155.

\section{Submit your next manuscript to BioMed Central and take full advantage of:}

- Convenient online submission

- Thorough peer review

- No space constraints or color figure charges

- Immediate publication on acceptance

- Inclusion in PubMed, CAS, Scopus and Google Scholar

- Research which is freely available for redistribution 